\title{
PENGARUH KUALITAS PRODUK DAN LAYANAN PURNA JUAL TERHADAP KEPUASAN PELANGGAN PENGGUNA SMARTPHONE MEREK XIAOMI DI FAKULTAS EKONOMI UNIVERSITAS KRISNADWIPAYANA
}

\author{
Wirdianto Abdul Jabar 1) \\ 1) Mahasiswa Program Studi Manajemen FE UNKRIS \\ Imam Wibowo ${ }^{2)}$ \\ 2) Dosen Program Studi Manajemen FE UNKRIS \\ Email: wibowoimam253@gmail.com \\ Nino Nopriandi ${ }^{3}$ \\ 3) Dosen Program Studi Manajemen FE UNKRIS \\ Alamat: Kampus UNKRIS, Jatiwaringin Jakarta Timur \\ Email: nopriandi@perkasagroup.net
}

\begin{abstract}
This research aims to know influence of product quality and after sales service on customer satisfaction using Xiaomi smartphones. The population and sample of this study were students of the economics faculty of the Krisnadwipayana University class of 2017 with a total of 58 students. Research analysis method using simple regression analysis technique and simultaneous regression analysis. The hypothesis test using the F test and $t$ test. The results of the study state that partially, product quality and after-sales service have a positive and significant effect on consumer satisfaction. Simultaneously, product quality and after-sales service have a positive and significant effect on consumer satisfaction.
\end{abstract}

Keyword: product quality, after sales service and customer satisfaction

\section{PENDAHULUAN}

Pada era yang digital jaman sekarang penggunaan teknologi terus bertambah. Salah satunya pengguna ponsel pintar atau yang biasa disebut smartphone. Smartphone menjadi salah satu teknologi yang sangat penting dimiliki pada jaman sekarang karena membantu manusia saling berinteraksi satu sama lain tanpa dibatasi oleh jarak maupun waktu. Kemudahan yang diberikan teknologi saat ini meliputi banyak hal, mulai dari edukasi, komunikasi maupun bisnis. Pada hakikatnya teknologi diciptakan untuk memenuhi kebutuhan manusia agar kehidupannya lebih mudah melakukannya segala hal.

Pertumbuhan dan perkembangan teknologi menyebabkan persaingan bisnis semakin ketat. Tidak sedikit perusahaan smartphone yang menawarkan berbagai macam bentuk dan bervariasi. Usaha-usaha yang telah ditetapkan perusahaan untuk mencapai tujuan mendapatkan banyak konsumen salah satunya ialah melalui pemasaran. Persaingan yang semakin ketat membuat perusahaan melaksanakan suatu strategi pemasaran yang efektif untuk menggaet konsumen baru dan mempertahankan konsumen lama. Salah satu cara untuk menarik minat konsumen adalah dengan memberikan kepuasan akan produk, memuaskan kebutuhan konsumen dari waktu ke waktu. Perusahaan tentu akan semakin sukses apabila mereka dapat mengerti kebutuhan dan keinginan yang dimiliki oleh konsumen dan mengutamakan kepuasannya. 
Menurut Xu, et al, (2017) layanan purna jual "membuat pelanggan merasa percaya bahwa produk yang mereka beli memiliki kualitas baik, mereka tidak lagi mengkhawatirkan bagaimana jika barang yang mereka beli rusak dan dimana tempat untuk mengklaim garansi sebab semua itu dapat dilakukan di jaringan after sale, maka dari itu layanan purna jual dapat meningkatkan kepuasan pelanggan". Kepuasan konsumen menjadi perhatian yang utama bagi kebanyakan perusahaan. Jika kinerja produk lebih rendah dari pada harapan, pelanggan akan kecewa; jika ternyata sesuai harapan, pelanggan akan puas; jika melebihi harapan, pembeli akan sangat puas. Perasaan - perasaan itu akan membuat apakah pembeli akan membeli produk tersebut dan akan membicarakan hal-hal yang menguntungkan atau tidak menguntungkan tentang produk tersebut dengan orang lain. Kepuasan konsumen merupakan konsep penting dalam konsep pemasaran. Melihat tingginya tingkat kepentingannya pada pemasaran, kepuasan telah menjadi subyek dari beberapa penelitian konsumen yang dilakukan cukup gencar oleh perusahaan. Hal ini dilakukan untuk mengetahui apakah keinginan konsumen yang sebenarnya.

Perusahaan perlu melihat pentingnya konsumen dipuaskan dengan memberikan kualitas produk serta pelayanan yang baik. Artinya, memberikan kinerja yang sama atau melebihi harapan konsumen, dengan tujuan untuk mendapatkan para konsumen yang loyal (setia) sehingga memberikan manfaat yang tinggi bagi perusahaan. Hal ini yang menjadi alasan pentingnya kepuasan konsumen bagi perusahaan. Dengan begitu konsumen juga akan sangat diuntungkan karena perusahaan mampu memberikan apa yang mereka inginkan sesuai dengan harapan. Menurut Ritonga (2011), "Kepuasan pelanggan muncul apabila harapan 3 pelanggan sesuai dengan keputusan pembelian yang telah dibuat". Kepuasan dapat dirasakan setelah individu membeli dan menggunakan produk atau layanan yang disediakan oleh perusahaan.

Xiaomi sebagai salah satu smartphone pendatang baru, banyak memiliki kelebihan sehingga dapat bersaing dengan smartphone lainnya. Agar dapat memenangkan persaingan, maka perusahaan memiliki strategi menawarkan produk untuk menawarkan produk yang mempunyai nilai lebih, sehingga dapat menarik minat konsumen dan untuk jangka panjang dapat menjadi pelanggan yang setia. Diantaranya adalah memberikan kepuasan melalui produk yang berkualitas seperti spesifikasi yang mumpuni, RAM yang besar, serta kamera yang jernih, dan yang tidak kalah pentingnya adalah merek yang mampu memberikan garansi bahwa produk yang dijual itu berkualitas. Seperti garansi yang diberikan xiaomi lebih dari 12 bulan, pelayanan servis yang memuaskan, dan cepat dalam menanggapi keluhan konsumen.

Xiaomi memang merupakan brand Cina yang sedang populer di pasaran saat ini dan sedang menjadi pembicaraan di Indonesia. Mulai dari strategi penjualan yang unik, produk yang selalu terjual habis dalam waktu singkat, dan spesifikasi yang canggih namun tidak mematok harga yang begitu mahal merupakan keunggulan dari brand Cina ini. Indonesia adalah negara berkembang yang sedang mengalami pertumbuhan kelas menengah yang pesat. Xiaomi nampaknya paham betul akan hal ini dengan menargetkan harga smartphone di kelas menengah di Indonesia. faktor emosional tidak mempengaruhi kepuasan pelanggan, biaya dan kemudahan mempengaruhi pelanggan kepuasan. Sementara secara simultan kualitas produk, harga, kualitas layanan, faktor 
emosional, dan biaya dan kemudahan mempengaruhi kepuasan pelanggan.

Jika 10 tahun lalu orang beranggapan bahwa produk Cina terutama dalam segi teknologi kurang berkualitas, barang tiruan alias menjiplak, tetapi kini perlahan produk Cina mulai mengikis kepercayaan tersebut. Salah satu brand Cina yang laris manis di Indonesia ialah Xiaomi. Masuknya Xiaomi ke pasar Indonesia menjadi ancaman nyata untuk para pesaing lama di pasar smartphone. Produk mereka diklaim mampu menawarkan segudang fitur yang tidak dimiliki oleh produk pabrikan lain, terutama dari segi harga dan performa.

Xiaomi sering mengeluarkan seriseri terbaru dikarenakan kebutuhan dan perkembangan teknologi semakin hari semakin meningkat, sehingga membuat Xiaomi memikirkan kepuasan konsumen yang menjadi loyalitas utama sebagai produsen smartphone terlaris kedua di Indonesia saat ini. Secara resmi Xiaomi, dijual dengan patokan harga yang murah dikelasnya dengan memikirkan kebutuhan ekonomi yang ada di Indonesia. Produk yang berada dipasaran saat ini telah mengalami banyak sekali perkembangan sehingga menimbulkan jumlah produk menjadi semakin bertambah dan muncul.

Oleh karena itu muncul keinginan untuk melakukan penelitian tentang pengaruh kualitas produk dan layanan purna jual terhadap kepuasan pelanggan karena kualitas produk dan layanan purna jual sangat berhubungan dengan kepuasan pelanggan. Pelanggan dikatakan puas apabila produk yang mereka gunakan atau beli merupakan produk berkualitas dan sesuai dengan harapan pelanggan, sedangkan layanan purna jual yang diberikan perusahaan kepada pelanggan berjalan dengan baik dan benar bahkan melebihi harapan mereka, maka akan timbul suatu kepuasan tersendiri bagi pelanggan.
Tujuan penelitian ini adalah untuk menganalisis pengaruh kualitas produk dan layanan purna jual terhadap kepuasan konsumen pengguna Smartphone Merek Xiaomi di Fakultas Ekonomi Universitas Krisnadwipayana.

\section{LANDASAN TEORI}

\section{Kepuasan Pelanggan}

Menurut Maryati dan Husda (2020) kepuasan adalah "efek yang dirasakan dari penggunaan barang dan layanan yang diberikan, sehingga barang dan layanan itu melewati standar pemakai". Ketika kebutuhan, keinginan, dan aspirasi pelanggan terpenuhi, kepuasan pelanggan akan terpenuhi. Menurut Tresiya, et al, (2019) kepuasan adalah "perasaan puas atau kecewa pada seseorang yang muncul setelah membandingkan persepsi atau kesan tentang kinerja produk, hasil dan harapan". Menurut Kotler dan Keller (2016), kepuasan adalah "perasaan senang atau kecewa seseorang yang dihasilkan dari membandingkan kinerja (atau hasil) yang dirasakan suatu produk atau layanan dengan harapan". Menurut Kotler dan Armstrong (2015) mendefinisikan kepuasan pelanggan sebagai adalah "sejauh mana kinerja yang dipersepsikan produk sesuai dengan harapan pembeli. Jika kinerja produk tidak sesuai harapan, pelanggan tidak puas. Jika kinerja sesuai dengan harapan, pelanggan merasa puas". Jika kinerjanya melebihi ekspektasi, maka pelanggan sangat puas atau senang.

Menurut Westbrook dan Reilly dalam Tjiptono (2014) kepuasan pelanggan adalah "respon emosional terhadap pengalaman-pengalaman berkaitan dengan produk atau jasa tertentu yang dibeli, gerai ritel, atau bahkan pola perilaku (seperti perilaku berbelanja dan perilaku pembelian), serta pasar secara keseluruhan". Berdasarkan definisi tersebut dapat disimpulkan bahwa kepuasan pelanggan adalah 
perasaan seseorang ketika membandingkan antara ekpektasi dan realita terhadap suatu produk ataupun jasa.

Faktor-faktor yang dapat menjadi penentu kepuasan pelanggan. Faktor yang menjadi penentu tingkat kepuasan pelanggan menurut Lupiyoadi (2014) adalah: 1). Kualitas produk, dimana pelanggan akan merasa puas bila hasil evaluasi mereka menunjukan bahwa produk yang mereka gunakan berkualitas. 2). Kualitas layanan, pelanggan akan merasa puas bila mereka mendapatkan layanan yang baik dan sesuai dengan yang diharapkan. 3). Emosional, Pelanggan akan merasa bangga dan mendapatkan keyakinan bahwa orang lain akan kagum terhadap dia bila menggunakan produk dengan merek tertentu yang cenderung mempunyai tingkat kepuasan yang lebih tinggi. Kepuasan yang diperoleh bukan karena kualitas dari produk tetapi dari nilai sosial yang membuat pelanggan menjadi puas terhadap merek tertentu. 4). Harga, Produk yang mempunyai kualitas yang sama tetapi menetapkan harga yang relatif murah akan memberikan nilai yang lebih tinggi kepada pelanggannya. 5). Biaya dan kemudahan, pelanggan akan semakin puas apabila relatif mudah, nyaman dan efesien dalam mendapatkan produk atau pelayanan.

Tjiptono (2014), menyampaikan terciptanya kepuasan pelanggan dapat memberikan beberapa manfaat diantaranya: 1) Hubungan perusahaan dengan konsumen menjadi harmonis. 2) Memberikan dasar yang baik bagi pembeli. 3) Dapat mendorong terciptanya loyalitas konsumen. 4) Membentuk rekomendasi dari mulut ke mulut yang menguntukngkan perusahaan. 5) Laba yang diperoleh meningkat.

Indikator kepuasan pelanggan; Kepuasan pelanggan sangat tergantung pada persepsi dan ekspektasi pelanggan, maka sebagai pemasok produk perlu mengetahui faktor-faktor yang mempengaruhinya. Menurut Tjiptono (2014) terdapat lima faktor yang dapat mempengaruhi kepuasan seorang pelanggan yaitu: 1) Kualitas produk, pelanggan akan merasa puas bila hasil evaluasi mereka menunjukkan bahwa produk yang mereka gunakan berkualitas. 2) Harga, produk dengan kualitas yang sama tetapi menetapkan harga yang relatif murah akan memberi nilai yang tinggi kepada pelanggannya. 3) Kualitas layanan, pelanggan akan merasa puas jika mereka mendapatkan pelayanan yang baik atau sesuai dengan harapannya. 4). Faktor emosional, pelanggan akan merasa bangga dan mendapatkan keyakinan bahwa orang lain kagum kepadanya bila menggunakan produk merek tertentu. 5) Biaya dan kemudahan untuk mendapatkan produk atau jasa, pelanggan yang tidak perlu mengeluarkan biaya tambahan atau membuang waktu untuk mendapatkan suatu produk, cenderung puas terhadap produk.

\section{Kualitas Produk}

Menurut Umami, et al (2016) kualitas produk yaitu "kapasitas suatu produk pada saat menjalankan suatu fungsi yang mencakup keunggulan produk dalam segi mutu, daya tahan, kemudahan penggunaan, akurasi, kualitas produk, atau fitur nilai”. Menurut Ibrahim dan Thawil (2018) Kualitas produk merupakan "kombinasi dari semua karakteristik barang atau jasa yang didapatkan dari penjualan, teknik manufaktur serta pemeliharaan sehingga dapat digunakan sesuai dengan kebutuhan pemakai". Menurut Kotler dan Armstrong (2015) mendefinisikan kualitas produk adalah "karakteristik dari produk atau layanan yang didasarkan pada kemampuannya untuk memenuhi kebutuhan pelanggan yang tersurat maupun tersirat". Sedangkan menurut Kotler dan Keller (2016), "kualitas produk adalah "kemampuan suatu barang 
untuk memberikan hasil atau kinerja yang sesuai bahkan melebihi dari apa yang diinginkan pelanggan". Menurut American Society pengertian kualitas adalah "totalitas fitur dan karakteristik dari suatu produk atau layanan yang menghasilkan kemampuannya untuk memenuhi kebutuhan yang dinyatakan atau tersirat".

Berdasarkan definisi tersebut dapat diketahui bahwa kualitas produk merupakan kemampuan suatu produk dalam memenuhi keinginan konsumen. Keinginan konsumen tersebut diantaranya daya tahan produk, keandalan produk, kemudahan pemakaian, serta atribut bernilai lainnya yang bebas dari kekurangan dan kerusakan.

Indikator kualitas produk; Kualitas produk memiliki dimensi yang dapat digunakan untuk menganalisis karakteristik dari suatu produk. Menurut Adisaputro (2014) kualitas produk memiliki empat indikator sebagai berikut: 1) Bentuk (Form) yaitu struktur fisik dari produk. 2) Keistimewaan Tambahan (Features) yaitu kelebihan dari produk yang lainya. 3) Kinerja (Performance) yaitu performa dari suatu produk untuk menjalankan sistem. 4) Daya tahan (Durability) yaitu ketahan suatu produk, baik keawetan maupun kondisi.

\section{Layanan Purna Jual}

Menurut Xu, Blankson, dan Prybutok (2017) "layanan purna jual membuat pelanggan merasa percaya bahwa produk yang mereka beli memiliki kualitas baik, mereka tidak lagi mengkhawatirkan bagaimana jika barang yang mereka beli rusak dan dimana tempat untuk mengklaim garansi sebab semua itu dapat dilakukan di jaringan after sale, maka dari itu layanan purna jual dapat meningkatkan kepuasan pelanggan". Menurut Tavakoli, et al. (2016) layanan purna jual adalah "rangkaian kegiatan yang terjadi setelah pembelian produk untuk mendukung pelanggan dalam menggunakan dan memperbaiki barang".

\section{Menurut Amrtrong}

menjelaskan bahwa "layanan purna jual merupakan layanan yang di sediakan untuk pelanggan setelah penjualan di lakukan dengan menyediakan layanan perbaikan dan pemeliharaan". Menurut Kotler dan Armstrong (2015) layanan purna jual "merupakan layanan tambahan yang kepada konsumen yang dapat membangun hubungan yang baik dan tahan lama dengan pelanggan". Menurut Sudarsono dan Edilius (2010) "mendefinisikan pelayanan purna jual atau after sale service sebagai jasa pelayanan yang meliputi perbaikan, penyediaan suku cadang, dan lain-lain yang diberikan oleh perusahaan kepada konsumen setelah produknya dibeli untuk jangka waktu tertentu". Pemberian Pelayanan purna jual biasanya dilakukan sebagai suatu bentuk tanggung jawab yang diberikan oleh penjual atas barang yang telah mereka jual. Pelayanan ini diberikan dalam bentuk pemberian garansi, penggantian barang-barang rusak, pemeliharaan dan penyediaan suku cadang. Berdasarkan beberapa definisi diatas dapat diketahui bahwa layanan purna jual merupakan adalah pelayanan yang diberikan oleh perusahaan kepada konsumen yang memiliki keluhan atau klaim setelah kegiatan jual-beli berakhir.

Indikator layanan purna jual menurut Kotler dan Armstrong (2014) memiliki empat indikator diantaranya adalah: 1) Guarantee (Garansi). Garansi diberikan kepada pelanggan agar pelanggan menjadi yakin bahwa produk yang mereka terima itu memiliki kualitas yang baik bebas dari kerusakan yang di sebabkan kesalahan dalam pengerjaan atau penggunaan bahan yang berkualitas buruk, yang berlaku dalam jangka waktu yang telah di tentukan. 2) Sparepart (Sukucadang), peran suku cadang ini sagat penting bagi konsumen karena 
ketika salah satu komponen produk sudah rusak maka diperlukan komponen yang baru dan ketika komponen yang baru itu tidak ada maka kehandalan produk tersebut akan menurun atau bahkan produk tersebut tidak biasa di pakai kembali. 3) Maintanace and repair (Pemeliharaan dan perbaikan), layanan ini dibutuhkan ketika sebuah produk memiliki jangka waktu pakai yang cukup lama yang dan membutuhkan perawatan berkala untuk menjaga kehandalan dari produk tersebut dan untuk memperbaiki segala kerusakan yang dialami oleh peroduk tersebut ketika masa pemakaian. 4) Facility and equipment (Fasilitas dan Peralatan), fasilitas dan perlengkapan yang memadai dapat membantu petugas untuk menyelesaikan masalah yang terjadi dengan produk tersebut, semakin canggih fasilitas dan perlengkapan maka semakin mudah petugas memperbaiki masalah yang ada di produk tersebut.

\section{METODE PENELITIAN}

Populasi dalam penelitian ini adalah semua mahasiswa/i Fakultas Ekonomi Universitas Krisnadwipayana strata 1 angkatan 2017 yang menggunakan smartphone Xiaomi sebanyak 58 mahasiswa/i. Penelitian yang diukur menggunakan skala semantik diferensial. Selanjutnya dilakukan pengujian instrumen data, metode analisis menggunakan analisis regresi linear sederhana dan berganda.

\section{HASIL PENELITIAN DAN PEMBAHASAN}

\section{Hasil Penelitian}

\section{Uji validitas instrumen variabel}

Dari perhitungan koefisien korelasi skor tiap butir pernyataan dari 58 responden tentang instrumen kualitas produk, dengan jumlah 16 pernyataan; instrumen layanan purna jual 16 pernyataan dan instrumen kepuasan konsumen 20 pernyataan dengan total skor setiap responden diperoleh hasil r hitung lebih besar dari r kritis 0,266. (Sugiyono, 2017)

\section{Uji reliabilitas}

Uji reliabilitas dilakukan dengan menggunakan Cronbach's Alpha. Dalam uji reliabilitas, suatu instrumen penelitian dapat diterima bila dalam kisaran Cronbach's Alpha > 0,6 maka instrumen penelitian dikatakan reliabel, jika nilai Cronbach's Alpha < 0,6 maka instrumen penelitian dikatakan tidak reliabel.

\begin{tabular}{lccc}
\hline \multicolumn{1}{c}{ Variabel } & $\begin{array}{c}\text { Cronbach's } \\
\text { Alpha }\end{array}$ & $\begin{array}{c}\text { Nilai } \\
(\mathbf{a})=\mathbf{5 \%}\end{array}$ & Keterangan \\
\hline Kualitas Produk & 0,997 & 0,6 & Reliabel \\
Layanan Purna Jual & 0,997 & 0,6 & Reliabel \\
Kepuasan Konsumen & 0,998 & 0,6 & Reliabel \\
\hline
\end{tabular}

Tabel 1: Hasil Uji Reliabilitas

Sumber: Hasil Pengolahan Data Primer, 2021 
Berdasarkan pada tabel 1, menunjukan bahwa seluruh item pertanyaan lebih besar dari nilai Cronbach's Alpha. Yang berarti seluruh

item pertanyaan yang berhubungan dengan kualitas produk, layanan purna jual, dan kepuasan konsumen dikatakan reliabel.

\section{Analisis regresi linear berganda}

Tabel 2: Pengaruh Kualitas Produk dan Layanan Purna Jual Terhadap Kepuasan Konsumen

\begin{tabular}{lcccccc}
\hline \multirow{2}{*}{ Variabel } & Mult. R & $\begin{array}{c}\text { R } \\
\text { Square }\end{array}$ & Konstanta & $\begin{array}{c}\text { Koefisien } \\
\text { Regresi }\end{array}$ & Sig. & $\boldsymbol{\alpha}$ \\
\cline { 2 - 7 } & 0,519 & 0,269 & 67,371 & $\begin{array}{c}0,371 \\
0,198\end{array}$ & 0,000 & 0,05 \\
\hline $\begin{array}{l}\text { Kualitas_Produk } \\
\text { Layanan_Purna_Jual }\end{array}$ & 0,5019 & & &
\end{tabular}

Pengujian Signifikan

F hitung $>\mathrm{F}$ tabel $=12,553>3,16$

Keterangan: Variabel Kinerja_Karyawan

Sumber: data diolah 2021

Berdasarkan Tabel 2, nilai $\mathrm{F}$ hitung sebesar 12,553 jika dibadingkan dengan $\mathrm{F}$ tabel sebesar 3,16, maka F hitung lebih besar dari $\mathrm{F}$ tabel $(12,553>3,16)$, artinya secara bersama-sama kualitas produk dan layanan purna jual berpengaruh signifikan pada tingkat nyata $99 \%$ terhadap kepuasan pelanggan pengguna smartphone merek Xiaomi di Fakultas Ekonomi Universitas Krisnadwipayana, atau dengan menggunakan $\mathrm{F}$ signifikan yaitu sebesar 0,000 lebih kecil dari tingkat kepercayaan 0,05. Nilai koefisien determinasi $\left(\mathrm{R}^{2}\right)$ sebesar 0.269 , artinya kualitas produk dan layanan purna jual memberikan kontribusi sebesar 26,9\% kepada kepuasan pelanggan pengguna smartphone merek Xiaomi di Fakultas Ekonomi Universitas Krisnadwipayana, sedangkan sisanya sebesar $73,1 \%$ disumbangkan faktor lain yang tidak dibahas dalam penelitian ini.

Persamaan Regresi $\mathrm{Y}=67,371+0,371$ $\left(\mathrm{X}_{1}\right)+0,198\left(\mathrm{X}_{2}\right)$
Kualitas produk dan layanan purna jual berpengaruh positif dan signifikan terhadap kepuasan pelanggan pengguna smartphone merek Xiaomi di Fakultas Ekonomi Universitas Krisnadwipayana pada tingkat nyata $99 \%$. Koefisien kualitas produk sebesar 0,371 artinya bahwa setiap peningkatan kualitas produk, maka kepuasan pelanggan pengguna smartphone merek Xiaomi di Fakultas Ekonomi Universitas Krisnadwipayana akan bertambah atau sebaliknya dengan asumsi layanan purna jual tetap. Koefisien layanan purna jual sebesar 0,198, artinya bahwa setiap penambahan layanan purna jual, maka kepuasan pelanggan pengguna smartphone merek Xiaomi di Fakultas Ekonomi Universitas Krisnadwipayana akan meningkat atau sebaliknya, dengan asumsi kualitas produk tidak berubah. Dengan demikian hipotesis pertama dapat diterima. 
Analisis reegresi linear sederhana

Tabel 3: Pengaruh Kualitas Produk Terhadap Kepuasan Konsumen

\begin{tabular}{lcccccc}
\hline \multirow{2}{*}{ Variabel } & $\mathbf{R}$ & $\begin{array}{c}\text { R } \\
\text { Square }\end{array}$ & Konstanta & $\begin{array}{c}\text { Koefisien } \\
\text { Regresi }\end{array}$ & Sig & $\boldsymbol{\alpha}$ \\
\cline { 2 - 7 } & 0,519 & 0,269 & 70,415 & 0,530 & 0,000 & 0.05 \\
\hline Kualitas_Produk & 0 & & & & \\
\hline Pengujian Signifikan & \multicolumn{7}{c}{ Parameter } \\
\hline t hitung $>$ t tabel $=4,539>1,673$ \\
\hline
\end{tabular}

\section{Keterangan: Variabel Kinerja_Karyawan}

Sumber: data diolah 2021

Berdasarkan Tabel 3, nilai koefisien determinasi $\left(\mathrm{R}^{2}\right)$ sebesar 0.269 , artinya kualitas produk memberikan kontribusi sebesar 26,9\% kepada kepuasan pelanggan pengguna smartphone merek Xiaomi di Fakultas Ekonomi Universitas Krisnadwipayana, sedangkan sisanya sebesar 73,1\% disumbangkan variabel lain yang tidak diteliti.

$$
\text { Persamaan Regresi } \mathrm{Y}=70,415+0,530\left(\mathrm{X}_{1}\right)
$$

Kualitas produk berpengaruh positif dan signifikan pada tingkat nyata 99\% terhadap kepuasan pelanggan pengguna smartphone merek Xiaomi di Fakultas Ekonomi Universitas Krisnadwipayana. Koefisien kualitas produk sebesar 0,530, artinya bahwa setiap peningkatan kualitas produk, maka kepuasan pelanggan meningkat.

Untuk menguji hubungan secara parsial kualitas produk terhadap kepuasan konsumen pengguna smartphone merek Xiaomi di Fakultas Ekonomi Universitas Krisnadwipayana signifikan atau tidak, dilakukan pengujian $\mathrm{t}$ hitung dibandingkan dengan $\mathrm{t}$ tabel dengan tingkat $\alpha=0,05$, hasilnya adalah $\mathrm{t}$ tabel $=$ 1,673. Berdasarkan perhitungan tersebut, dapat dinyatakan bahwa nilai t hitung $=$ 4,539 dan $\mathrm{t}$ tabel $=1,673$ atau $\mathrm{t}$ hitung $>\mathrm{t}$ tabel $(4,539>1,673)$, maka dapat diartikan terdapat pengaruh yang positif dan signifikan kualitas produk terhadap kepuasan konsumen pengguna smartphone merek Xiaomi di Fakultas Ekonomi Universitas Krisnadwipayana. Dengan demikian hipotesis kedua dapat diterima.

Tabel 4: Pengaruh Layanan Purna Jual Terhadap Kepuasan Konsumen

\begin{tabular}{lcccccc}
\hline & \multicolumn{7}{c}{ Parameter } \\
\cline { 2 - 7 } & $\mathbf{R}$ & $\begin{array}{c}\text { R } \\
\text { Square }\end{array}$ & Konstanta & $\begin{array}{c}\text { Koefisien } \\
\text { Regresi }\end{array}$ & Sig & $\boldsymbol{\alpha}$ \\
\hline Layanan Purna Jual & 0,477 & 0,228 & 86,734 & 0,361 & 0,000 & 0.05 \\
\hline Pengujian Signifikan & & & & & \\
\hline t hitung $>$ t tabel $=4,065>1,673$ \\
\hline
\end{tabular}

Keterangan: Variabel Kinerja_Karyawan

Sumber: data diolah 2021

Berdasarkan Tabel 4, nilai koefisien determinasi $\left(\mathrm{R}^{2}\right)$ sebesar 0.228 , artinya layanan purna jual memberikan kontribusi sebesar 22,8\% kepada kepuasan pelanggan pengguna smartphone merek Xiaomi di Fakultas Ekonomi Universitas Krisnadwipayana, sedangkan sisanya sebesar $77,2 \%$ disumbangkan variabel lain yang tidak diteliti. 
Persamaan Regresi $\mathrm{Y}=86,734+0,361$ $\left(\mathrm{X}_{2}\right)$

Layanan purna jual berpengaruh positif dan signifikan pada tingkat nyata 99\% terhadap kepuasan pelanggan pengguna smartphone merek Xiaomi di Fakultas Ekonomi Universitas Krisnadwipayana. Koefisien layanan purna jual sebesar 0,361, artinya bahwa setiap peningkatan layanan purnaa jual, maka kepuasan pelanggan meningkat.

Untuk menguji hubungan secara parsial layanan purna jual terhadap kepuasan pelanggan pengguna smartphone merek Xiaomi di Fakultas Ekonomi Universitas Krisnadwipayana signifikan atau tidak, dilakukan pengujian $\mathrm{t}$ hitung dibandingkan dengan $\mathrm{t}$ tabel dengan tingkat $\alpha=0,05$, hasilnya adalah $\mathrm{t}$ tabel $=1,673$. Berdasarkan perhitungan tersebut, dapat dinyatakan bahwa nilai t hitung $=4,065$ dan $\mathrm{t}$ tabel $=1,673$ atau $\mathrm{t}$ hitung > t tabel $(4,065>1,673)$, maka dapat diartikan terdapat pengaruh yang positif dan signifikan layanan purna jual terhadap kepuasan pelanggan pengguna smartphone merek Xiaomi di Fakultas Ekonomi Universitas Krisnadwipayana. Dengan demikian hipotesis ketiga dapat diterima.

\section{Pembahasan}

\section{Pengaruh Kualitas Produk Terhadap Kepuasan Pelanggan}

Kualitas produk mendukung peningkatan kepuasan pelanggan dikarenakan ukuran layar Smartphone Xiaomi sesuai dengan kebutuhan pengguna, smartphone Xiaomi memiliki fitur yang unggul dibanding smartphone lainnya, smartphone Xiaomi mempunyai kapasitas RAM yang sesuai dengan kebutuhan, dan baterai smartphone xiaomi tidak mudah rusak. Hasil penelitian ini sesuai dengan hasil penelitian yang dilakukan oleh Aulia dan Hidayat, (2017) kualitas produk memiliki pengaruh positif dan signifikan terhadap kepuasan pelanggan.

\section{Pengaruh Layanan Purna Jual Secara Parsial Terhadap Kepuasan Pelanggan}

Layanan purna jual mendukung peningkatan kepuasan pelanggan dikarenakan jaminan memberikan servis gratis selama masa garansi, suku cadang Smartphone Xiaomi bisa didapatkan di luar service center resmi, kemudahan dalam pemeliharaan smartphone xiaomi, proses perbaikan smartphone xiaomi dilakukan dengan cepat. Hasil penelitian sesuai dengan penelitian yang dilakukan oleh Ernoputri, et al, (2016) dengan hasil penelitian variabel layanan purna jual memiliki pengaruh positif dan signifikan terhadap kepuasan pelanggan.

Pengaruh Kualitas Produk dan Layanan Purna Jual Secara Simultan Terhadap Kepuasan Pelanggan

Kualitas pelayanan dan layanan purna jual mendukung peningkatan kepuasan pelanggan dikarenakan kualitas produk Smartphone Xiaomi sesuai dengan apa yang diharapkan, harga smartphone xiaomi sesuai dengan kualitas produknya, layanan service center smartphone Xiaomi mampu memberikan informasi yang lengkap, produk smartphone Xiaomi membuat pelanggan menjadi loyal, Produsen smartphone Xiaomi sering memberikan potongan harga pada event tertentu. Hasul penelitian ini sesuai dengan penelitian yang dilakukan oleh Widjaya (2019) kualitas pelayanan dan layanan purna jual memiliki pengaruh positif dan signifikan terhadap kepuasan pelanggan.

\section{KESIMPULAN DAN SARAN}

\section{Kesimpulan}

Berdasarkan hasil penelitian yang telah dilakukan dan telah dibahas dalam pembahasan, maka dapat diambil kesimpulan yang dapat diuraikan sebagai 
berikut: 1). Hasil penelitian menunjukan bahwa kualitas produk dan purna jual mendukung peningkatan kepuasan pelanggan smartphone Xiaomi 2). Hasil penelitian menunjukan bahwa kualitas produk mendukung peningkatan kepuasan pelanggan smartphone Xiaomi. 3). Hasil penelitian menunjukan bahwa layanan purna jual mendukung peningkatan kepuasan pelanggan smartphone Xiaomi.

\section{Saran}

1) Bagi Perusahaan Smartphone Xiaomi: a). Dari segi kualitas produk, perusahaan harus lebih meningkatkan kualitas produk pada smartphone Xiaomi seperti meningkatkan spesifikasi baik dari segi kamera hingga layar sehingga kinerja smartphone Xiaomi lebih unggul dari smartphone lainya. b). Dari segi layanan purna jual, perusahaan harus memberikan kemudahan bagi konsumen dalam proses mengklaim garansi smartphone Xiaomi sehingga konsumen akan merasa puas terhadap layanan yang diberikan.

2) Bagi Peneliti; Bagi peneliti selanjutnya disarankan untuk memperkaya ranah penelitian menambah variabel-variabel yang belum diuji dalam penelitian ini. Misalnya pada variabel citra merek, kualitas pelayanan, harga dan lainlain yang dapat mempengaruhi kepuasan konsumen.

3) Bagi Pembaca; Penelitian ini dapat digunakan sebagai pembelajaran dalam meneliti variabel kualitas produk dan layanan purna jual. Dan untuk para pembaca yang akan melakukan penelitian selanjutnya disarankan agar memasukan variabel lain yang sudah diteliti dalam penelitian ini.

\section{DAFTAR PUSTAKA}

Adisaputro. Gunawan. 2014. Manajemen Pemasaran. Yogyakarta. UPP STIM YKPN.

Amstrong. Kotler. 2015. Marketing an Introducing Prentice Hall twelfth edition. England: Pearson.

Aulia, Maslikhatul dan Hidayat, Imam. 2017. Pengaruh Kualitas Produk, Kualitas Pelayanan dan Harga Terhadap Kepuasan Konsumen Amanda Brownies. Jurnal Ilmu dan Riset Manajemen. Vol. 6, No. 5, Mei 2017. Hal. 1-17. ISSN: 24610593.

Ernoputri, Darayani., Arifin, Zainul dan Fanani, Dahlan. 2016. Pengaruh Layanan Purna Jual Terhadap Kepuasan Konsumen (Survei pada Pengguna Produk LG di Malang Town Square (Matos) Malang Jawa Timur). Jurnal Administrasi Bisnis (JAB) Vol. 30 No. 1 Januari 2016. Hal. 79-86

Ibrahim, M., dan Thawil, S. M. 2018. Pengaruh Kualitas Produk Dan Kualitas Pelayanan Terhadap Kepuasan Pelanggan Mobile Broadband di Kota Palembang. Jurnal Keuangan Dan Bisnis, 16(1), 43. Https://Doi.Org/10.32524/Jkb.V16i 1.364

Kotler, Philip and Gary Amstrong. (2016). Prinsip-prinsip Pemasaran. Edisi13. Jilid 1. Jakarta: Erlangga

Kotler, Philip and Kevin Lane Keller, 2016. Marketing Managemen, 15th Edition, Pearson Education Inc.

Lupiyoadi, Rambat. 2014. Manajemen Pemasaran Jasa. Edisi 3. Jakarta: Salemba Empat.

Maryati, F., dan Husda, N. E. 2020. Pengaruh Fasilitas Dan Kualitas Pelayanan Terhadap Kepuasan Pelanggan Pada Holiday Hotel di Kota Batam, VIII (1), 19-26. 
Ritonga, Pandapotan. 2011. Analisis Pengaruh Kesadaran dan Kepatuhan Wajib Pajak Terhadap Kinerja Kantor Pelayanan Pajak (KPP) dengan Pelayanan Wajib Pajak Sebagai Variabel Intervening di KPP Medan Timur. Skripsi. Universitas Islam Sumatera Utara, Medan.

Sudarsono dan Edilius. 2010. Koperasi dalam Teori dan Praktek. Jakarta: Rineka Cipta

Sugiyono. 2017. Metode Penelitian Kuantitaif, Kualitatif dan $R \& D$. Bandung: PT Alfabet.

Tjiptono, Fandy. 2014. Manajemen Jasa. Edisi Kedua. Yogyakarta: Penerbit Andi.

Tavakoli, Gholamreza., Heidari, Omid dan Majid Feyz Arefi. Toward a Conceptual Model of Customer Satisfaction for Manufacturing Organization and Presenting a Three-Phases Approach. Volume 3 No 7 Hal.411-1442. 2016

Tresiya, D., Djunaidi, D., dan Subagyo, H. 2019. Pengaruh Kualitas Pelayanan Dan Kenyamanaan Terhadap Kepuasan Konsumen
(Studi Pada Perusahaan Jasa Ojek Online Go-Jek Di Kota Kediri). JIMEK: Jurnal Ilmiah Mahasiswa Ekonomi, $\quad 1(2), \quad 208$. Https://Doi.Org/10.30737/Jimek.V $1 \mathrm{i} 2.310$

Umami, R., Rizal, A., dan Sumartik. 2016. Pengaruh Kualitas Produk, Harga Dan Kualitas Pelayanan Terhadap Kepuasan Konsumen Kedai Warsu Coffe Cafe, 250

Westbrook, \& Reilly. 2004. Dalam F. Tjiptono, Pemasaran Jasa (Pertama ed., hal. 349). Malang: Bayumedia Publishing.

Widjaya, Ingnasius Irvan. 2019. Analisis Pengaruh Kualitas Produk, Persepsi Harga, dan Kualitas Layanan Purna Jual Terhadap Kepuasan Pelanggan Di PT. Hargen Nusantara. Jurnal Ekonomi dan Bisnis. Vol. 17 No. 1 (2019). Hal. 1-11.

$\mathrm{Xu}, \mathrm{Lu} ., \mathrm{Blankson}$, Charles dan Prybutok, VR. 2017. Relatif Constribusi of Product Quality and Service Quality in the Automobile Industry. In Quality Management Journal. Vol. 24 No.1 January 2017. Hal. 21-36. 